\title{
Report of the Secretary-General on children and armed conflict in Afghanistan
}

\section{Summary}

The present report, which has been prepared pursuant to Security Council resolution 1612 (2005), is presented to the Council and its Working Group on Children and Armed Conflict as the first country report on the situation of children and armed conflict in Afghanistan. The report covers the period from 1 July 2007 to 15 August 2008.

The report focuses on grave violations perpetrated against children in Afghanistan and identifies parties to the conflict, both State and non-State actors, who commit grave abuses against children. In particular, the report highlights the fact that children have been recruited and utilized by State and non-State armed groups and that non-State armed groups such as the Taliban continue to train and use children as suicide bombers. The report sheds light on the detention of children accused of association with armed groups by the Government of Afghanistan, and international military forces in violation of Afghan law and international best practice. The report also discusses the worrisome increase in the number of children victims of attacks against schools and communities by non-State armed groups, including the ever increasing number of children inadvertently killed during engagements by international and Afghan forces. Finally, the report surveys the need for greater attention to the problem of sexual violence against children, in particular against boys, in the context of the ongoing armed conflict in Afghanistan.

The report acknowledges the significant challenges in addressing child rights violations in Afghanistan and outlines a series of recommendations to end the recruitment and use of children as well as other grave violations of children's rights. It recommends that all parties to the conflict facilitate access to their areas of operation and ensure the safety of staff for monitoring and reporting purposes. It asks the United Nations, in consultation with the Government of Afghanistan and international forces, to investigate ways and means of extending monitoring and reporting to hitherto inaccessible conflict areas of Afghanistan. 


\section{Introduction}

1. The present report, prepared pursuant to Security Council resolution 1612 (2005), covers the period from 1 July 2007 to 15 August 2008 and highlights trends and patterns of violations committed against children in the context of the armed conflict in Afghanistan. The establishment of a monitoring and reporting mechanism in Afghanistan was supported by President Hamid Karzai, and endorsed on 28 July 2008 by the United Nations country team, based on the recommendations of the country Task Force on Monitoring and Reporting, which was set up on 27 July 2008. The report identifies parties to the conflict responsible for grave violations and abuses committed against children covered under the monitoring and reporting mechanism endorsed by the Security Council in its resolution 1612 (2005) and highlights avenues for reinforced and targeted monitoring as well as interventions that might be developed to prevent violence and respond to the needs of the victims. It also contains a number of recommendations with a view to securing strengthened action for the protection of war-affected children in Afghanistan. Although the country Task Force on Monitoring and Reporting was as thorough as possible in preparing this first report, gaps in data are inevitable given the difficulties in documenting and investigating, the lack of access and the limited time available.

\section{Political, military and social developments in Afghanistan}

\section{A. Background on latest developments relating to the conflict}

2. The Taliban emerged in 1994 from southern Afghanistan and launched an armed movement against the various factions that were then fighting each other. After the fall of Kabul to the Taliban in 1996, most of these factions joined together as the Northern Alliance and continued to resist the Taliban. By September 2001, the Taliban controlled approximately 90 per cent of the country. During its regime, in areas under its control, the Taliban interpreted religious and tribal law in their most ultra-conservative forms, thereby trampling women's rights and denying education to children. At the same time, the country became a haven for activity of international groups using terror tactics, including Al-Qaida.

3. In November 1999, the Security Council, by its resolution 1267 (1999), introduced mandatory sanctions against key members of the Taliban and Al-Qaida. Following the events of 11 September 2001, international military forces entered Afghanistan in October 2001 and removed the Taliban from power. Afghan political movements met in Bonn, Germany, in December 2001 at a conference held under the auspices of the United Nations, which resulted in the establishment of an interim administration, led by Hamid Karzai, who was declared President for six months. President Karzai's term was extended during the emergency Loya Jirga held in June 2002. On 6 December 2001, the Security Council, in its resolution 1383 (2001), endorsed the Bonn agreement, which authorized the establishment of the International Security Assistance Force (ISAF) to help the transitional government maintain security. On 22 March 2002, the Security Council, by its resolution 1401 (2002), established the United Nations Assistance Mission in Afghanistan (UNAMA). The Bonn agreement also provided for the creation of a new constitution, which was adopted by the constitutional Loya Jirga in January 2004. Presidential elections on 9 October 2004 resulted in the election of Hamid Karzai, 
by 55.4 per cent of the vote. Parliamentary elections held in September 2005 led to the establishment of the 249-seat National Assembly, which was inaugurated in December 2005, marking the formal conclusion of the Bonn political process.

4. Despite the significant progress on the political front, the Afghan Government is faced with ongoing opposition from the Taliban and other groups. In the course of 2008, the security situation has deteriorated further. While the main focus of the insurgency remains the southern and eastern parts of the country, where it has historically been strong, insurgent influence has intensified in areas that were previously relatively calm, including in the provinces closest to Kabul. The number of security incidents rose to 983 in August 2008, the highest number since the fall of the Taliban in 2001, representing a 44 per cent increase compared with the same month in 2007. While armed clashes between Afghan and international security forces on the one hand and insurgents on the other have continued to increase in number and intensity, asymmetric attacks carried out by the Taliban have increased to an even greater degree.

5. In March 2008, the Security Council extended the mandate of UNAMA. In its resolution 1806 (2008) the Council reiterated its concern about civilian casualties as well as the recruitment and use of children by Taliban forces. The Council also recalled the importance of implementing resolution 1612 (2005) in Afghanistan and requested the strengthening of the child protection component of UNAMA. The Council also called upon UNAMA to strengthen cooperation with ISAF. On 6 March 2008, I appointed Mr. Kai Eide as my Special Representative for Afghanistan.

\section{B. Armed forces and armed groups operating in Afghanistan}

\section{Afghan National Security Forces}

6. Afghanistan ratified the Convention on the Rights of the Child in 1994. The Optional Protocol to the Convention on the Rights of the Child on the involvement of children in armed conflict was signed and ratified on 23 September 2003. The Parliament has yet to ratify the 1999 Convention concerning the Prohibition and Immediate Action for the Elimination of the Worst Forms of Child Labour (Convention No. 182) of the International Labour Organization (ILO). The minimum age of recruitment into the Afghan National Security Forces, composed of the bodies described below, is 18 years.

\section{Afghan National Army}

7. The Afghan National Army, created in 2002 and now more than 58,000 strong, has already deployed 72 per cent of its personnel. In September 2008, the Afghan Minister of Defence proposed an increase in the force strength to 122,000 and an extended deployment time frame to 2012 in order to cope with the anticipated threat level in the country.

\section{Afghan National Police}

8. The Afghan National Police is the primary law enforcement agency of the Government of Afghanistan. In May 2007, the size of the force was increased to 82,000 from 62,000 in response to increased demand for policing as a result of rising insurgency and law enforcement obligations. There is a high casualty rate in 
the force, with approximately 1,119 members of the force killed between March 2007 and March 2008.

\section{Afghan National Auxiliary Police}

9. The Afghan National Auxiliary Police was created as a temporary force to assist the Afghan National Police with its counter-insurgency activities. As of December 2007, the total strength of the Auxiliary Police stood at 10,895, although its sanctioned strength is 11,271. Through the focused districts development programme in selected areas, the force should be integrated into the Afghan Uniform Police, which is part of the Afghan National Police, the main civil police force.

\section{National Directorate of Security}

10. The National Directorate of Security is the intelligence agency of the Government of Afghanistan. It is one of the largest security sector agencies operating under a still classified decree. The Directorate exercises extensive powers, including for detaining, interrogating and investigating, prosecuting and sentencing people alleged to have committed crimes against national security, and it also takes part in military-related operations.

\section{Anti-government elements}

\section{Taliban}

11. Although the Taliban has carried out attacks in other provinces, its focus is largely concentrated in the south and east of the country. The group, led by Mullah Muhammad Omar, is the largest and allegedly the most organized of the armed groups operating in the country and, as with other armed groups operating in Afghanistan, it utilizes terror tactics against both military and civilian targets.

\section{Haqqani network}

12. The Haqqani network, led by Jalaluddin Haqqani, a former adviser to Mullah Omar of the Taliban, is closely linked to that group and is operative especially in the eastern provinces of Khost and Paktya. The Haqqani network is suspected of having masterminded the attack on Kabul's Serena Hotel in January 2008, the attack on a military parade during a ceremony at Kabul Stadium in April 2008 and the attack on the Indian Embassy in July 2008.

\section{Hezb-i-Islami}

13. Gulbuddin Hekmatyar is the leader of Hezb-i-Islami Gulbuddin, a group that is mostly active in the east of Afghanistan and in the provinces surrounding Kabul. The group focuses its military operations on suicide attacks and attacks on the Afghan National Security Forces and international forces.

\section{Jamat Sunat al-Dawa Salafia}

14. Jamat Sunat al-Dawa Salafia is an Islamic fundamentalist group led by Hajir Ruhollah. The network's activities are very limited because of the tension between this group and Hezb-i-Islami Gulbuddin. As a result, the Salafists are only present in 
parts of Kunar and Nuristan provinces. In general, the group focuses its military operations on actions against international military forces.

\section{Other armed groups}

\section{Illegal armed groups}

15. The Afghan Government's disbandment of illegal armed groups programme targets the estimated 1,800 illegal armed groups active in the country, which still possess approximately 336,000 weapons. In addition to the risk represented by those weapons, the armed groups represent an obstacle to the restoration of the rule of law. Some factions targeted by the countrywide demobilization, disarmament and reintegration programme have neither been fully disarmed nor mainstreamed into the regular political system. As a result, several armed groups remain heavily involved in illegal activities such as narcotics and weapons trafficking.

\section{International military forces}

\section{International Security Assistance Force}

16. Under the command of NATO, ISAF is a multinational force composed of soldiers from 40 troop-contributing nations acting under Chapter VII of the Charter of the United Nations. The Security Council, by its resolution 1510 (2003), authorized the expansion of the ISAF mandate to support the Afghan Transitional Authority and its successors in the maintenance of security in areas of Afghanistan outside of Kabul and its environs. ISAF is currently composed of approximately 52,700 soldiers organized into 18 brigades, one Marine Expeditionary Unit, 26 provincial reconstruction teams and other elements. The Southern Region is the strongest regional command, with 23,800 troops, followed by the Eastern Region with 16,200 troops, the Central Region with 5,900, the Northern Region with 4,300 and the Western Region with 2,500 soldiers.

\section{Operation Enduring Freedom}

17. There are approximately 12,000 troops deployed within Operation Enduring Freedom, led by the United States of America. These troops operate under separate command from ISAF and are primarily focused on training and equipping the Afghan National Security Forces and conducting operations throughout Afghanistan.

\section{Visit of the Special Representative of the Secretary-General for Children and Armed Conflict and the monitoring and reporting mechanism}

18. My Special Representative for Children and Armed Conflict, Ms. Radhika Coomaraswamy, accompanied by the Director of Emergency Operations of the United Nations Children's Fund (UNICEF), Mr. Louis Georges, visited Afghanistan from 28 June to 3 July 2008 at the invitation of the Government. The visit was intended to establish the monitoring and reporting mechanism on grave violations committed against children in armed conflict, pursuant to Security Council resolution 1612 (2005), and to assess the impact of the conflict first hand. The Special Representative visited Kabul, Jalalabad and Gardez and met with President 
Karzai, Ministers, officials of ISAF and the Combined Forces Command, representatives of international agencies, international and Afghan non-governmental organizations, religious leaders and a number of children and families affected by the conflict.

19. The Special Representative expressed her concerns about reports of children being used by anti-Government elements, the death and injury of children during the fighting, the detention of children, sexual violence against children and the continuing attacks on schools, teachers and schoolchildren. She also expressed concern about the unintentional death of and injury to children as a result of the operations of international military forces and the Afghan National Security Forces. She stressed that United Nations monitoring agents should have unimpeded access to all detention facilities where children are believed to be present, and that "worrisome allegations about sexual violence against boys by armed actors should also be confronted despite their sensitive nature".

20. The first meeting of the country Task Force on Monitoring and Reporting took place on 27 July 2008, following the visit of the Special Representative. The monitoring and reporting mechanism was endorsed by the United Nations country team on 28 July, with the support of President Karzai. The task force is co-chaired by UNAMA and UNICEF and its current members are the United Nations High Commissioner for Refugees (UNHCR), the United Nations Office on Drugs and Crime (UNODC) and the World Health Organization (WHO). The Afghanistan Independent Human Rights Commission has accepted an invitation to become a member of the task force. Child protection actors outside the United Nations system welcomed the establishment of the monitoring and reporting mechanism and are currently discussing safe and appropriate ways to engage with it.

\section{Grave violations and abuses of children's rights: incidents and trends}

21. Information and insights on the direct impact of the conflict on children in Afghanistan is drawn from a variety of sources that undertake independent investigations involving, where possible, victim and eye-witness accounts that are cross-checked with other testimonies. However, given access and security issues, not all incidents automatically come to the attention of child protection actors, nor can they be independently investigated, meaning, in effect, that available data is likely to underrepresent the actual impact of conflict on children. Furthermore, notwithstanding ongoing efforts to address such limitations, much of available data is not age and sex-disaggregated.

\section{A. Recruitment and use of children by armed forces and armed groups}

22. Children have been used by all parties throughout the 30 years of armed conflict in Afghanistan. Since the completion of the Government's demobilization and reintegration of 7,444 under-age soldiers in 2003, which did not, however, fully disarm all factions, there has been no monitoring of children vulnerable to further recruitment or re-recruitment. Allegations of recruitment of children by armed groups have been received from all regions, particularly from the south, south-east 
and east. Under-age recruitment is also reported to be prevalent in some areas, with high concentrations of returnees or internally displaced persons, including in areas around internally displaced persons' camps in Helmand and Kandahar provinces and in Wardak and Ghazni provinces, both of which received a high number of returnees during 2007. Recruitment of internally displaced and returnee children has not, however, been specifically documented. The monitoring of such cases has not been possible due to the growing insecurity and inaccessibility of certain areas to the United Nations and implementing partners. Child recruitment, or the threat thereof, has been reported as one of the causes for their displacement, for example by 10 families displaced from the Muqur district of Baghdis province to the Shaidaiee internally displaced persons' settlement in Herat province. Internally displaced families also reported that the general threat of recruitment by armed groups is higher "because the Taliban pay more than the police".

23. A study of suicide attacks by UNAMA has documented cases of children who have allegedly been used as suicide bombers by the Taliban. Most of these children were between 15 and 16 years of age and were tricked, promised money or forced to become suicide bombers. On 16 May 2008, a boy of approximately 12 years of age approached a joint ISAF/Afghan National Army foot patrol in Panjwayi district, Kandahar province spreading his hands. The suicide vest he carried is believed to have been remotely detonated.

24. There are concerns that, due to a recruitment process that has insufficient age determination procedures, there are children in the ranks of the Afghan National Auxiliary Police. Children have allegedly been spotted among units sent ahead of military operations in the Southern Region. These allegations have not been fully verified. The country Task Force on Monitoring and Reporting has documented cases of children recruited by the Afghan National Police, including in the north, south and south-east of the country. For example, in one northern province, seven children aged 16 to 18 are working at the provincial headquarters of the Afghan National Police, conducting regular policing tasks, including patrols, guarding police posts or carrying out checkpoint duties. In the south, two 14-year-old boys recruited into the Afghan National Police were successfully released after an intervention with the authorities by child protection actors.

\section{B. Children detained due to their alleged association with armed groups}

\section{Detention by the authorities of Afghanistan}

25. Particular incidents highlight several interconnected challenges: under-age recruitment, insufficient age-verification procedures and poor treatment of detained children due to their alleged association with armed groups. In a northern province, a 17-year-old boy joined the Afghan National Police with a falsified identification document. While on duty at a checkpoint that came under attack by the Taliban he was taken hostage, but was later released after handing over his weapon to the assailants. The child was later arrested and detained on grounds of having aided the enemy. The age-verification procedure initiated by his lawyer proved that he was under 18. While the lawyer argued that the child could only be tried in a juvenile court, the military court proceeded. The boy was later acquitted. 
26. Since international military forces entered Afghanistan in 2001, an unknown number of children have been captured and arrested by Afghan law enforcement agencies and international military forces owing to their alleged association with armed groups. Information received from the Ministry of Justice and protection partners shows that from October 2007 to July 2008 at least 28 children were detained on charges related to national security; all were male, the majority between 15 and 17 years of age at the time of their arrest, the youngest a 12-year-old. During the reporting period, child protection actors have documented 13 such cases. The detention of children for national security issues is in contravention of the provisions of the Afghan juvenile code.

27. The sporadic access of monitoring bodies to detention facilities run by the National Directorate of Security is of concern, particularly given the reports received by the Afghan Independent Human Rights Commission and UNAMA of harsh treatment inflicted upon children. Full access to these facilities would allow proper monitoring and permit appropriate interventions for the cases dealt with outside the Afghan legislative framework. Indeed, while children in conflict with the law must be referred to juvenile rehabilitation centres, children as young as 12 have been detained by the National Directorate of Security. Most children reported no access to legal assistance or legal documentation. Some reported that they had been subjected to threats and ill-treatment while being interrogated for information about their activities while associated with armed groups.

28. In addition, the situation of specific groups such as foreign children or children surrendered to State authorities should be given specific attention. This is illustrated in the case of two Pakistani boys who remained without contact with their families for months. The country Task Force on Monitoring and Reporting also documented the case of a 15-year-old boy detained by the National Directorate of Security after surrendering to the police. He had been lured by the Taliban into taking part in a suicide operation. The boy is still detained, and has now spent more than five months in the custody of the National Directorate of Security without appropriate judicial follow-up.

\section{Detention by international military forces}

29. There are allegations of unlawful and arbitrary detention in facilities run by international military forces, although reported cases of children being detained remain limited. UNAMA and the Afghan Independent Human Rights Commission have tried with little success to gain access to such facilities, and have no access at all to the "Theatre internment facility" at Bagram Airbase, headquarters of the United States forces in Afghanistan. Allegations have been recorded of children kept incommunicado, as substantiated by the case of a 17-year-old boy arrested during a combined operation by the Afghan National Army and the United States-led coalition. Reportedly detained by a United States provincial reconstruction team for a month without access to a lawyer or contact with his family, he was subsequently transferred to the National Directorate of Security before the Primary Court ordered his release.

30. In its recent report to the United Nations Committee on the Rights of the Child, the United States acknowledged that 10 children below the age of 18 were in administrative detention at Bagram Airbase. The report also indicated that the United States does not have a specific policy for dealing with juveniles arrested or 
detained as a result of the conflict. The report further states that eight Afghan juveniles between 13 and 17 years of age have been held at Guantanamo Bay since 2002; six have been released and two face criminal charges, including charges of war crimes. For example, Omar Khadr, a Canadian citizen, faces charges for alleged offences committed at age 15 in Afghanistan, purportedly as a child soldier. Khadr was captured by United States forces after a firefight in July 2002. On 4 June 2007, he was charged with war crimes before the United States military commission for allegedly killing an American soldier. Despite his age at the time of the alleged offences, international standards of juvenile justice were not applied. Khadr was detained in Guantanamo Bay beginning in November 2002, where he was allegedly subjected to abusive interrogations and prolonged solitary confinement. He has since been released from solitary confinement. During the trial, the defence argued that the United States should consider Khadr as a victim.

31. Human rights actors will seek collaboration with the international military forces to ensure that children arrested due to alleged involvement with parties to the conflict and detained, whether inside or outside Afghanistan, are dealt with according to legal standards. This is to avoid breaching standards of justice for children, as documented by various human rights organizations.

\section{Killing and maiming of children}

32. From August 2007 to July 2008, UNAMA recorded 1,722 civilian deaths as a result of the conflict. The issue of civilian casualties, particularly child casualties, continues to be of great concern. Below are some of the numerous incidents that have affected children.

33. Children have been the victims of suicide attacks orchestrated by anti-Government elements that primarily target national and international security forces, governmental infrastructures and associated individuals. On 10 July 2007, in Dehrawot district, Uruzgan province, a suicide attack, using a body-borne improvised explosive device targeted an ISAF convoy, reportedly causing the death of 12 schoolchildren. On 6 November 2007, a suicide bomber targeted a delegation of Members of Parliament on a road in Pul-i-Khomri district, Baghlan province. Police and bodyguards opened what appears to have been indiscriminate fire after the explosion. Various independent reports indicate that among the dead were 52 schoolchildren and five teachers, out of approximately 70 persons. Around half of the injured were said to be students. Although the exact number of casualties caused by the shooting rather than by the explosion is undetermined, reports confirmed that the casualty toll was aggravated by the fact that the police and private security guards fired indiscriminately into the crowd. On 17 February 2008 in Kandahar province, 67 people, including six children, were killed and more than 90 wounded in a suicide bomb attack. On 7 July 2008, a vehicle-borne improvised explosive device was used in an attack on the Indian Embassy in Kabul, resulting in the deaths of some 50 civilians, among whom were a number of children.

34. Children have been the unintentional victims of joint military operations conducted by the Afghan National Security Forces and the international military forces, including an incident on 6 April 2008 in Doab district, Nuristan province, in which a joint operation of the international military forces and the Afghan National Army reportedly resulted in at least 18 civilians killed, including 4 women and 7 
children, 15 injured, including 2 women and 3 children, and as many as 150 homes destroyed. On 30 April 2008, in Kabul, a joint National Directorate of Security/Afghan National Police force reportedly cordoned off a house where anti-Government elements were hiding. As the anti-government elements attempted to flee the area, two civilians, one woman and one child, were killed in the ensuing firefight.

35. Civilian casualties, particularly child casualties, have been unintentionally caused by aerial bombardments and ground attacks as a result of imprecise targeting or mistaken identity. On 12 January 2008, in Tagab district, Kapisa province, international military forces reportedly carried out two air attacks against a compound allegedly housing a senior Taliban militant. In the first attack, two children, aged 14 and 4, were killed. In a similar incident on 27 May 2008, as a result of an air strike by international military forces in Manogay district, Kunar province, 14 civilians, including 9 children were allegedly killed; 2 other children were injured. According to international military forces, no civilian casualties were recorded as precision munitions had been used; 7 alleged anti-Government elements were killed. On 6 July 2008, in Dih Bala district, Nangahar province, it was alleged by Afghan authorities that an air support operation by international military forces, while attempting to target a suspected gathering of anti-Government forces, struck a wedding procession resulting in the deaths of 47 civilians, including 30 children, and injuries to 11 others.

36. Night searches and raids are a feature of international military activities. However, it has been noted that the international military forces have adjusted their procedures in order to minimize the killings of or injury to children. Yet children are still victims of such operations. For example, on 3 February 2008, in Bakwa district, Farah province, 11 civilians, including 3 children under 14 years of age, were reportedly killed as a result of a night raid by forces of Operation Enduring Freedom on an alleged hideout for anti-government elements. In another incident, on 19 March 2008, in Nadir Shah Kot district, Khost province, 6 civilians, including 2 children and a woman, were killed during a night raid purportedly carried out by Operation Enduring Freedom.

\section{Incidents related to unexploded ordinance and other explosive remnants of war}

37. An estimated 728 square kilometres of land, containing 5,027 hazardous areas with anti-personnel and anti-tank mines and a large number of explosive remnants of war from both the previous and current periods of conflict still require clearance, particularly in the east, north and south-east regions.

38. During the reporting period, 81 children were killed and 332 sustained injuries due to unexploded ordnance and explosive remnants of war. Eighty-nine per cent of the victims were boys. The majority of these incidents were caused by unexploded ordnance (36.6 per cent), anti-personnel mines (22.8 per cent) and anti-tank mines (19.1 per cent). Improvised explosive devices, booby traps, cluster ammunition and fuses are responsible for the remainder of incidents. For example, on 17 December 2007, in Tirin Kot, Uruzgan province, a family with 3 children was reportedly killed when their motorcycle struck a roadside improvised explosive device. On 17 April 2008, 2 children were reportedly killed and 1 injured by the detonation of an 
unexploded ordnance (artillery shell) in district 17 in Kabul. On 27 May 2008, in Daman district, Kandahar province, 3 children were reportedly killed when an improvised explosive device went off in a culvert close to where they were playing.

\section{E. Abduction of children}

39. Very few cases of children having been abducted as a result of the conflict have been documented. However, due to the security vacuum prevailing in some areas, criminal kidnapping of children is reported frequently. In one case, antigovernment elements in the Western Region abducted the child of a Provincial Prosecutor who had launched a criminal investigation against the group. The child was killed soon after his abduction.

\section{F. Attacks on schools and hospitals}

1. Incidents involving the Taliban and anti-government elements affecting the education sector

40. A primary analysis of the 722 incidents affecting education recorded by UNICEF from 2004 to July 2008 reveals that the South is the most affected region: 230 of such incidents took place between July 2007 and June 2008 alone, an escalation over previous years.

41. Acts of violence have historically targeted schools as representative of the central Government or of perceived foreign interference, and the Taliban and its proxies are reportedly responsible. Furthermore, the Taliban denied nearly all girls the right to attend school while in power, a position they still brutally enforce. For instance, while girls' schools represent only 14.8 percent of the total number of primary, secondary and high schools in Afghanistan, they are affected by some 50 per cent of the recorded incidents. From 22 to 28 April 2008 in Logar province, four schools, including three girls' schools, were burned by unidentified armed elements.

42. The burning of schools is by far the most frequent type of incident carried out on educational facilities. For example, in the capital of Logar province, from April to May 2008, three schools were set on fire. In Kandahar city, three schools were burned from January to March 2008. Threats against schools, staff, teachers, pupils or parents often take the form of "night letters", threatening notes or messages left in public places at night, and are frequently attributed to the Taliban. For example, during the summer of 2007, "night letters" were left in a school in Sari Pul province demanding that teachers stop teaching girls, warning them that the Taliban would soon return to power. Threats and attacks are also believed to target facilities built by provincial reconstruction teams, as a result of which a significant number of such facilities remain unused, including the Teacher Training Institute of Ghazni province. Teachers and education personnel have also been victims of targeted killings, as evidenced by the attacks in Jawzan province, in which the principal of a primary girls' school was shot dead in October 2007 and, in Kunduz province, in which two teachers were killed in May 2008. These cases, which are currently under police investigation, are attributed to anti-government elements, but no further action has been taken to date. 
43. Schools have been targeted for armed attacks and improvised explosive devices and other explosive devices have been placed in or around them. Schools have also been affected by military interventions taking place in the vicinity, sometimes resulting in the killing or injury of teachers and pupils. For example, in Kapisa province in June 2008, an artillery shell fired by international military forces landed in a school compound, killing a boy. Checkpoints, police posts or military camps established by parties to the conflict within the immediate vicinity of educational facilities have also affected school security. In Wardak province in June 2008, one student was killed and four others injured as a result of an armed altercation between the Afghan National Police and alleged members of the Taliban near their school.

Table 1

Percentage of incidents affecting boys', girls' and coeducational schools

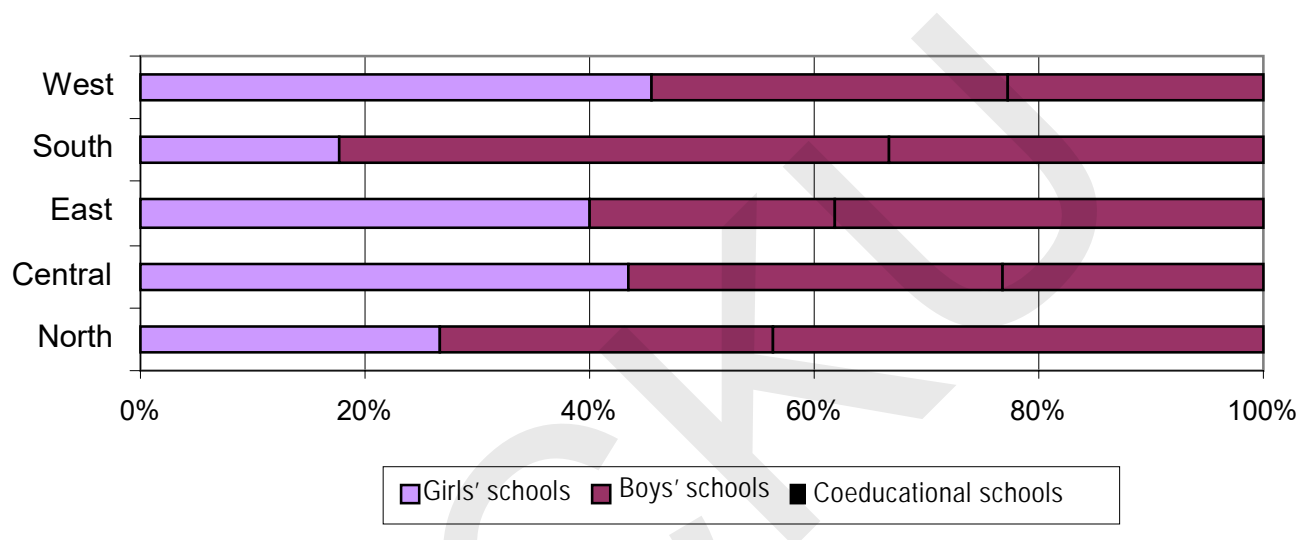

2. Incidents involving the Taliban and anti-government elements affecting the health sector

44. WHO and UNICEF have recorded incidents related to the armed conflict affecting the health sector, including operations carried out by anti-government elements against health centres, threats, killings and injury of staff, looting of facilities, forced closure of centres and programmes, and intimidation of organizations supporting health programmes. WHO reports that dozens of health workers have been abducted and/or killed in the past two years throughout the country. For example, in June 2008 armed elements in one northern province shot a doctor and a security guard dead in a medical clinic run by an international non-governmental organization.

45. Health facilities are not protected from the direct impact of military operations. In May 2008, for instance, in Farah province, the headquarters of the Afghan National Police was reportedly attacked by armed elements using rocketpropelled grenades. A nearby health clinic was damaged during the crossfire. In June 2008, one of two rockets fired towards Asadabad city, Kunar province, by suspected members of the Taliban hit the public hospital, killing one person and injuring two. The use of health facilities by the Afghan National Security Forces, including the one occupied by the Afghan National Police since the spring of 2008 in Kandahar province, is likely to complicate the security of these facilities in the conflict. 
46. The deteriorating security situation has prompted Afghan health officials to shut down some 36 health facilities in the southern and eastern provinces, depriving hundreds of thousands of children of basic health services. The Ministry of Public Health stated in May 2008 that more than 360,000 people in Helmand, Kandahar, Farah, Zabul and Paktika provinces have been deprived of health services due to insecurity. For instance, the closure of the Khairkhana Basic Health Centre in Badghis province in mid-July 2008 by anti-government elements, affected some 30,000 persons. The current insecurity is also hampering vital polio eradication efforts, as demonstrated by the 15 new cases reported to date in 2008. In Kandahar province, four incidents by Taliban elements against vaccinators took place on 2 August 2008, the second day of the campaign.

47. These incidents also affect efforts to expand the number of women health professionals throughout the country. Less than 30 per cent of health facilities have a female health worker reflecting the difficulty of recruiting qualified female staff and the problems faced by female workers operating in rural or insecure areas. As the major portion of the population of working women in the country, female health staff are particularly vulnerable to intimidation and threats from the Taliban and other conservative elements. The absence of female staff directly affects the delivery of child and maternal health services as women are reluctant to seek care from male health professionals.

\section{G. Sexual violence perpetrated against children}

48. There are a number of substantive reports of children, especially boys, being sexually abused and exploited by members of the armed forces and armed groups. For example, two police officers in a south-eastern province who were arrested after the intervention of child protection actors for sexually abusing a 15-year-old boy were released after allegedly bribing the authorities. In a similar incident, in the north, a 16-year-old boy reportedly recruited into the Afghan National Army after providing a falsified identity document was subsequently sexually abused by two soldiers. There is insufficient protection for victims of or witnesses to violence, and very few cases reach the prosecution stage. Fear of violent retaliation against victims and families was cited as a factor by reliable sources. In addition, given the lack of specific legislation on the subject of sexual violence, victims are often arrested and charged with adultery.

49. While most of the victims do not wish their experience to be reported, it is possible to discuss certain incidents involving personnel of the Afghan National Security Forces where the cases were appropriately dealt with by the authorities. For instance, a member of the Afghan National Army active in northern Afghanistan raped an 11-year-old girl and was sentenced to 15 years imprisonment by a military court in early 2008. A 12-year-old boy and an adult male relative employed in a police post who were sexually abused by three police officers over an unknown period of time filed a complaint with the support of the Child Protection Action Network. The perpetrators were sentenced to 10 years imprisonment. In a southern province, a 16-year-old boy, stopped on the pretext of an identity check by a police officer, was subsequently raped. He reported the abuse to service providers who helped him to file a complaint. The case is being prosecuted. 
50. Violence against children, specifically of a sexual nature, occurs particularly during times of instability. The practice of "bacha baazi" (boy-play) consists of boys kept cloistered and used for sexual and harmful social entertainment by warlords and other armed group leaders. This practice, like any violence against children, is strongly condemned by Islam and by all religious and by governmental as well as cultural leaders. Prosecution of a small number of cases has been confirmed by the country Task Force on Monitoring and Reporting, and more initiatives, including studies on the issue of child sexual abuse, are being developed. However, law enforcement officials and human rights activists highlighted difficulties in preventing the practice, addressing the violence and prosecuting the perpetrators more consistently.

\section{H. Denial of humanitarian access to children}

51. Humanitarian access has become increasingly restricted in conflict-affected areas owing to the activities of anti-government elements. The United Nations has now designated 79 districts as "extreme risk" areas that are inaccessible to programme delivery by United Nations agencies. During the reporting period, the Afghan NGO Safety Office reported 71 incidents against non-governmental organizations attributed to anti-government elements, including beatings, searches, threats and abductions, as well as attacks using explosives/improvised explosive devices, mortars, missiles and other arms. Attacks against humanitarian workers by anti-government elements have increased and many aid agencies have restricted the scale and scope of their operations as a result. Since 2003, 38 staff have been killed and 47 injured. During the reporting period alone, 10 staff have been killed and 20 injured. The assassination of three international aid workers and one national staff of the International Rescue Committee on 13 August 2008 in Logar province, responsibility for which has been claimed by the Taliban, is the most recent episode. This has also adversely affected demining efforts, particularly in the south and south-east.

52. While severe drought and an increase in food prices have had a dramatic impact on the lives of millions of Afghans, especially children, insecurity further jeopardizes the delivery of essential humanitarian assistance. In many provinces where road transport firms refuse to risk attacks, the World Food Programme (WFP) has not been able to send sufficient quantities of supplies for its programmes, including its "food-for-education" operation, which benefits about 1.5 million school children on a daily basis. For instance, on 24 July 2008, in Farah province, 49 trucks were attacked by armed elements; over 320 metric tons of food, enough to feed about 38,400 people for a month, was looted. On 29 July 2008, WFP announced that 300,000 students from the southern provinces had not received its assistance, mainly due to insecurity.

53. Insecurity has also impeded the provision of assistance to families recently returned from Pakistan or deported from the Islamic Republic of Iran to areas that are inaccessible to humanitarian personnel, including the 83,000 refugees returned from Pakistan in 2007 and the approximately 5,000 Afghan families deported from the Islamic Republic of Iran who have mostly resettled in Farah and Nimruz provinces. 


\section{Dialogue and action plans to redress violations and abuses committed against children}

54. Experience and expertise in the monitoring of child rights violations in the context of the armed conflict has been limited to date. Existing human and child rights monitoring and investigation activities have been obstructed by the lack of safe access to conflict-affected areas and numerous acts of violence committed against aid workers by anti-government elements. In this vein, there is a need for the United Nations in Afghanistan to engage in an open discussion with the Government on the need for a strategy which recognizes that it is imperative for the United Nations country team to engage in action plans with all parties to conflict to end the practice of child soldiering in Afghanistan as spelled out in Security Council resolutions 1539 (2004) and 1612 (2005). Furthermore, the members of the country Task Force on Monitoring and Reporting should, in the coming three months, devise a plan of how, in the light of the prevailing deteriorating security situation, they might interface with the Government, international military forces and other relevant parties in the field to devise a system of alert and access for monitoring and verification in areas where the United Nations and its partners have little or no access.

\section{Follow-up and programmatic response to violations and abuses committed against children}

55. Afghanistan is a party to most of the major international human rights treaties. Since 2002, the country has adopted legislative changes relevant to the well-being of children. The Technical Advisory Group on Women and Children in Justice and the Criminal Law Committee of the Law Reform Technical Working Group, supported, inter alia, by the United Nations Office on Drugs and Crime, are specifically dealing with juvenile justice policies and programmes and are being mobilized to work on children in armed conflict-related legal reforms. A number of other initiatives are in place to address the violations and abuses committed against children's rights, as described below.

\section{A. Recruitment and use of children by armed forces and armed groups}

56. Under the monitoring and reporting mechanism there will be a discussion of the possible revitalization of community networks involved in the disarmament, demobilization and reintegration of children. In addition, the UNICEF offices in Afghanistan and Pakistan held a meeting in July 2008 at which they reviewed crossborder concerns related to children associated with armed groups and armed forces.

57. Child protection actors have welcomed juvenile-specific provisions, including on offences relating to children associated with armed groups, in the law on combating terrorist offences adopted in 2008. The law states that when an offence has been committed by individuals below the age of 18, the 2005 juvenile code will apply. In January 2008, UNICEF began a capacity-building initiative for local non-governmental organizations active in the field of human rights to develop a monitoring system aimed at reducing the unlawful detention of children. In June 
2008, UNICEF initiated a dialogue with the National Directorate of Security to ensure due process for all juveniles and the implementation of the juvenile protection measures of the new anti-terrorist law.

\section{B. Killing and maiming of children}

58. Efforts to underline the importance of independent monitoring have gained increased attention. At a meeting on the protection of civilians held in August 2007 ISAF acknowledged that mistakes had been made during operations, noting that, in addition to specialized training of all ground forces to promote observance of principles applicable in armed conflict, a review of its standard operating procedures was in progress, including mechanisms to share information on civilian casualties arising from its operations. The Afghan Government and ISAF have reportedly adjusted tactics and have used internal and external investigative mechanisms. While positive, the effectiveness of these initiatives needs to be fully assessed, in particular the inclusion of provisions specific to children.

59. More effective coordination between the national and international security forces operating in Afghanistan is required to allow a clear system of accountability, particularly with regard to incidents affecting children taking place during operations involving the troops of ISAF, Operation Enduring Freedom, the Afghan National Security Forces or other elements present at Bagram Airbase.

60. The Mine Action Programme for Afghanistan, overseen by the United Nations Mine Action Centre for Afghanistan, pending its full transfer to the Government of Afghanistan, is the world's largest and longest-running programme for the removal of mines and explosive remnants of war. Some 6,000 mine action personnel work for non-governmental organizations and international private companies. To increase access to affected areas, the community-based mine clearance approach is used, by which demining teams are formed from members of affected communities. Targeted activities are being conducted, with interventions in UNHCR centres near Pakistan and the Islamic Republic of Iran and the establishment of child-friendly safe play areas in 22 provinces. Access to physical rehabilitation services is hindered by many obstacles, including poverty, distance, lack of security and political divisions. The rehabilitation needs of child mine survivors (as well as those of other people with disabilities) are seldom met.

\section{Attacks on schools and hospitals}

61. To tackle the increased security incidents affecting education, in 2006 the Ministry of Education deployed two school and child protection officers per province to monitor and improve the school security environment. While some officers were successful in mobilizing community leaders to initiate a dialogue with perpetrators of violence, their overall ability has been questioned. Successful community mobilization initiatives have also taken place. For example, in the Western Region, in 2007, the Governor held a meeting of religious leaders, tribal elders and technical departments with the aim of reopening six schools and one health centre; all the affected facilities reopened and since then no incident has been reported. 
62. In September 2007, the immunization campaign took advantage of the "Peace Day". While UNAMA called for a total cessation of violence, WHO and UNICEF encouraged all parties to respect the immunization efforts and, as a consequence, only a few incidents were reported. More than 10,000 vaccinators visited areas in the districts missed during the year due to security concerns.

\section{Sexual violence perpetrated against children}

63. Afghan legislation on child abuse, including sexual abuse, is not in line with the Convention on the Rights of the Child. These issues are mostly covered by the outdated penal code or brought to local, informal justice mechanisms (for example through shura or jirga systems), where customary law applies. The limitation of the Afghan judicial system in investigating and prosecuting perpetrators of sexual violence and in allocating compensation to survivors perpetuates a culture of silence and impunity. Although taboo surrounding the subject of sexuality is widespread, making it difficult to openly address sexual violence, there have been initiatives with different scopes and focus. The Ministry of Women's Affairs, assisted by the United Nations Development Fund for Women (UNIFEM), is developing a database of cases of violence against women. The database, which unfortunately does not include abuses against boys, is likely to increase attention to sexual violence in general and consequently to the incidents perpetrated against children by parties to the conflict.

\section{Recommendations}

64. I urge all anti-government elements who are party to the conflict to immediately stop the use, exploitation and recruitment of children and recommend that Afghan National Security Forces develop appropriate age verification procedures and take appropriate measures to improve the protection of children.

65. In addition I encourage all parties to the conflict to enter into a dialogue with the country Task Force on Monitoring and Reporting with a view to halting grave violations of children's rights, as stipulated by the Security Council in its resolution 1612 (2005), and to ensure that information on violations committed against children in armed conflict is collected and disseminated to all appropriate actors.

66. In this regard, I encourage the Government of Afghanistan to intensify its efforts to prosecute all perpetrators of crimes committed against children and to ratify ILO Convention No. 182. I also call upon the Afghan authorities to introduce legislation aimed at criminalizing the recruitment of children in armed conflict and to consider enacting legislation necessary to give effect to the Rome Statute of the International Criminal Court.

67. I strongly urge the Taliban and other anti-government elements to immediately cease attacks against civilians, especially children, and civilian objectives. The United Nations country team in Afghanistan is encouraged to engage with the Afghan Government on means to advocate the cessation of such attacks. All parties to the conflict are urged to comply with principles of international law, to recognize and maintain the neutrality and safety of schools, hospitals, religious institutions, 
including their personnel, as "zones of peace" and to publicly declare an end to such practices.

68. I call upon international military forces and Afghan National Security Forces to improve standing operating procedures and rules of engagement, in particular by including special protection measures pertaining to children.

69. I urge the Government of Afghanistan and international military forces to ensure due process for all juveniles detained because of their alleged association with armed groups, regardless of the arresting authority.

70. I further request the Government of Afghanistan and international military forces to grant the United Nations and human rights monitoring bodies full access to all their detention facilities, including the National Directorate of Security and the Bagram Airbase.

71. I condemn in the strongest possible terms the attacks against humanitarian actors by the Taliban and other anti-government elements, in particular the killings and abductions, and call upon all parties to respect principles of international humanitarian and human rights law and to ensure the safety and protection of all those engaged in humanitarian action. In this regard, I also call upon community and religious leaders to publicly condemn attacks against humanitarian workers and to assist in developing appropriate measures for the protection of humanitarian actors and their programmes.

72. I welcome the efforts of my Special Representative to strengthen the child protection capacity of UNAMA, including by deploying child protection advisers.

73. I request the United Nations country team and the donor community to provide additional support to national programmes and initiatives to enhance the protection of children in Afghanistan.

74. I encourage the Government of Afghanistan to implement more fully laws and programmes to prevent and punish sexual violence and to support victims, monitor grave sexual violations against boys as well as girls and work with my team in Afghanistan to study ways and means of combating harmful practices, including that of bacha baazi, with the support of Afghan religious leaders and civil society.

75. I call upon the country Task Force on Monitoring and Reporting to present a plan within three months time, on ways and means to interface with Government, international military forces and other relevant parties to extend the monitoring and reporting mechanism mandated by Security Council resolution 1612 (2005) to all conflict areas of Afghanistan.

76. I request respective United Nations country teams and agencies to develop a regional framework of cooperation and information exchange in order to better address cross-border issues such as child recruitment and abduction. 